Freedman, L. R. (1967). Annals of Internal Medicine, 66, 697

Gutman, L. T., Winterbauer, R. H., Turck, M., Wedgwood, R. J., and Petersdorf, R. G. (1968). In Microbial Protoplasts, Spheroplasts and $L$-forms, ed. L. B. Guze, p. 391 . Baltimore, Williams and Wilkins.

Hanson, L. A. (1973 a). Fournal of Infectious Diseases. In press.

Hanson, L. A. (1973 b). Personal communication.

Hanson, L. A., and Winberg, J. (1967). In Pyelonephritis, ed. H. Losse and M. Kienitz, p. 106. Stuttgart, Thieme.

Hanson, L. A., Holmgren, J., Jodal, U., and Winberg, J. (1969). Acto Paediatrica Scandinavica, 58, 506.

Hanson, L. A., et al. (1971). In Renal Infections and Renal Scarring, ed. P. Kincaid-Smith and K. Fairley. Melbourne, Mercedes.

Heptinstall, R. (1966). Pathology of the Kidney. Boston, Little, Brown and Co. Hodson, C. J. (1965). Proceedings of the Royal Society of Medicine, 58, 785.

Holmgren, J., Hanson, L. A., Holm, S. E., and Kaijser, B. (1971). International Archives of Allergy and Applied Immunology, 41, 463.

Kaijser, B., Brorson, J. E., and Seeberg, S. (1972). Acta Pathologica et Microbiologica Scandinavica, Section B, 80, 777.

Kalmanson, G. M., and Guze, L. B. (1968). In Microbial Protoplasts, Spheroplasts and L-forms, ed. L. B. Guze, p. 406. Baltimore, Williams and Wilkins.

Kimmelstiel, P., Kim, O. J., Beres, J. A., and Wellman, K. (1961). American Fournal of Medicine, 30, 589.

Kincaid-Smith, P. (1955). Lancet, 2, 1263.
Kleeman, C. R., Hewitt, W. L., and Guze, L. B. (1960). Medicine, 39, 3. Longcope, W. T., and Winkenwerder, W. L. (1933). Bulletin of the Fohns Hopkins Hospital, 53, 255.

McGovern, J. H., and Marshall, V. F. (1969). Fournal of Urology, 101, 668. MacGregor, M. (1970). Archives of Disease in Childhood, 45, 159.

Penn, I. A., and Breidahl, P. D. (1967). Australian and New Zealand Fournal of Surgery, 37, 163.

Platt, R., and Dawson, J. (1950). Quarterly fournal of Medicine, 19, 33.

Sanford, J. P., Hunter, B. W., and Donaldson, P. (1962). Fournal of Experimental Medicine, 116, 285.

Saphir, O., and Taylor, B. (1952). Annals of Internal Medicine, 36, 1017

Smith, J. F. (1962). Fournal of Clinical Pathology, 15, 522.

Tan, H. K., and Heptinstall, R. H. (1969). Laboratory Investigation, 20, 62.

Turck, M., Gutman, L. T., Wedgwood, R. J., and Petersdorf, R. G. (1968). In Microbial Protoplasts, Spheroplasts and L-forms, ed. L. B. Guze, p. 415. Baltimore, Williams and Wilkins.

$\mathrm{Uhr}$, J. W., and Möller, G. (1968). Advances in Immunology, 8, 81.

Winberg, J., Andersen, H. J., Hanson, L. A., and Lincoln, K. (1963). British Medical fournal, 2, 524.

Winberg, J., et al. (1967). Acta Paediatrica Scandinavica, Suppl. No. 177, p. 42

Winberg, J., Larsson, H., and Bergström, T. (1971). In Renal Infections and Renal Scarring, ed. P. Kincaid-Smith and K. Fairley. Melbourne, Mercedes.

\title{
Benzodiazepines and Tricyclic Antidepressant Plasma Levels
}

\author{
GERALD SILVERMAN, R. A. BRAITHWAITE
}

British Medical fournal, 1973, 3, 18-20

\section{Summary}

Twelve patients acted successfully as subjects to study what effect if any the benzodiazepines nitrazepam, diazepam, oxazepam, and chlordiazepoxide might have on steady-state plasma levels of nortriptyline and amitriptyline. No significant detectable effect was discovered. In view of the known interaction effects of other alternative tranquillizing drugs and hypnotics it seems reasonable to choose benzodiazepines wherever possible when anxiolytics or hypnotics need to be added during treatment of depression with tricyclic antidepressants.

\section{Introduction}

There is now a rapidly growing interest in drug interactions which may occur during psychiatric treatment. Particular attention has been paid to the way in which one drug may alter the plasma concentration of another, and much of the experimental results to date relate to plasma concentrations of tricyclic antidepressants. Depressive illness rarely presents without significant insomnia, and there is also commonly present anxiety and agitation. It is quite usual therefore for hypnotics and sedatives to be prescribed in addition to antidepressants. These additional drugs generally belong to one of three classes: barbiturates, phenothiazines, and benzodiazepines. Alexanderson et al. (1969) found that patients on nortriptyline who had also received a variety of barbiturates had lower steady-state plasma levels than their non-barbiturate

\footnotetext{
University Department of Psychiatry, Whiteley Wood Clinic, Sheffield S10 3TI

GERALD SILVERMAN, M.B., M.R.C.PSYCH., Lecturer in Psychiatry

Poisons Unit, Guy's Hospital, London SE1 9RT

R. A. BRAITHWAITE, A.R.I.C., Research Biochemist
}

controls. Hammer et al. (1967) found a fall of about half in the established steady-state plasma level of desipramine in a single subject when exposed to phenobarbitone. Burrows and Davies (1971) similarly found a dramatic fall in nortriptyline plasma level in a subject due to amylobarbitone. Barbiturates have for some time been known to be very potent inducers of hepatic microsomal enzymes in man (Conney, 1967, 1969; Prescott, 1971). These enzymes are responsible for the metabolism of many drugs, and it is as a result of their induction that barbiturates can effectively shorten the half lives of tricylcic antidepressants and thereby lower their plasma levels. Phenothiazines can exert the opposite effect. Gram and Over $\varnothing$ (1972) showed a reduced metabolism of imipramine and nortriptyline with concomitant perphenazine medication, presumably due to competition in the hepatic enzyme systems. Moody et al. (1967) found a considerable rise in plasma imipramine level with the addition of chlorpromazine in one subject. There is now evidence that the therapeutic efficacy of tricyclic antidepressants is related to plasma level. Assberg et al. (1971) obtained a curvilinear relation with reduced efficacy at both lower and higher plasma levels of nortriptyline. Braithwaite et al. (1972), for amitriptyline, found a simple positive linear correlation but Grüvstad (1973) has applied an alternative statistical analysis to their data and shown that it supports the curvilinear result of Åsberg. Burrows et al. (1972) and later work by KraghSørensen et al. (1973) do not show such clear relations however. Nevertheless it seems highly desirable to confine additional medication to drugs which do not substantially affect tricyclic antidepressant plasma levels during the treatment of depressed patients. The purpose of the present study was to discover what effect if any benzodiazepines might have on steady-state nortriptyline and amitriptyline plasma levels.

\section{Method}

Ideally, patients taking no other drugs than nortriptyline or amitripryline on a fixed oral dose were to be the subjects for the investigation. Achievement of steady-state plasma levels was assumed to have taken place when patients had been on the antidepressant for at least seven days. This is in accord with 
our own preliminary findings and those of Kragh-Sørensen $\epsilon t$ al. (1973). No patients were admitted as subjects if they had had other drugs or electric convulsion therapy in the period less than three weeks before starting the antidepressant. Benzodiazepine medication was added after initial blood samples had been collected for estimations of steady-state plasma levels. Many patients had to be removed from the study for one or more of the following reasons: the dosage of the antidepressant had to be altered either because of side effects or failure to improve; the antidepressant had to be terminated early on; additional drugs could not be ethically withheld before achievement of steady-state; the patient objected to further venepunctures; or there was obvious unreliability in taking medication. In other cases standards of neatness had to be compromised a little for clinical reasons (see below). Eventually 12 patients acted as subjects, four inpatients and eight outpatients. There were five males and seven females. All were judged to be suffering from depressive illness suitable for treatment with either nortriptyline or amitriptyline by one of us (G.S.) and all were directly under his care. In all cases the major part of the daily dose was given at night. Patients were informed that their treatment would be partly constrained by the experimental study and were asked if they wished to be included. Blood was collected by venepuncture at about the same time of day for each individual patient, variations in timing being rarely more than about one hour and usually much less. Except in a few instances, when smaller volumes of blood were used, $20-\mathrm{ml}$ samples of blood were collected into lithium heparin tubes, centrifuged at 3,000 r.p.m. within 15 minutes, and the plasma was stored as paired samples of about $5 \mathrm{ml}$ each at $-40^{\circ} \mathrm{C}$. Nortriptyline and amitriptyline estimations were eventually performed by gas chromatography according to the method of Braithwaite and Widdop (1971). In most cases differences between values for each of the paired samples were well below $5 \%$, and each level is expressed as the mean value of the two paired samples. At first the effect of nitrazepam was studied and it became clear that this had no detectable effect on plasma levels. At the same time Breckenridge and Orme (1971) reported that they could not find any effects on Warfarin levels attributable to nitrazepam and that there was other evidence that it was free from enzyme induction properties. It was then felt reasonable for ethical reasons to study some subsequent subjects for the effect of other benzodiazepines even though they began a fixed nightly dose of nitrazepam for insomnia at the start of antidepressant therapy.

\section{Results}

The average duration during which subjects were exposed to the benzodiazepine drugs and during which plasma levels were being estimated was about three weeks, though for some this was much longer. In some subjects it was possible to eventually alternate between different benzodiazepines for periods at a time while continuing to sample for plasma levels. Despite this seemingly untidy procedure, inspection of the actual levels clearly shows that there was no truly detectable effect by these drugs. Statistical examination, however, would have been an unnecessarily difficult exercise in dealing with these longer-term results and actual illustrations of them will be provided in a future report on long-term studies. Inspection of tables I and II will show that 11 subjects provided data which was suitable for a simple statistical analysis, and the $t$ test only confirms what is evident from naked eye examination of the resultsnamely, that there is no substantial difference in plasma levels before and after benzodiazepine medication. Typical individual results in more detail are shown in figs. 1 and 2.

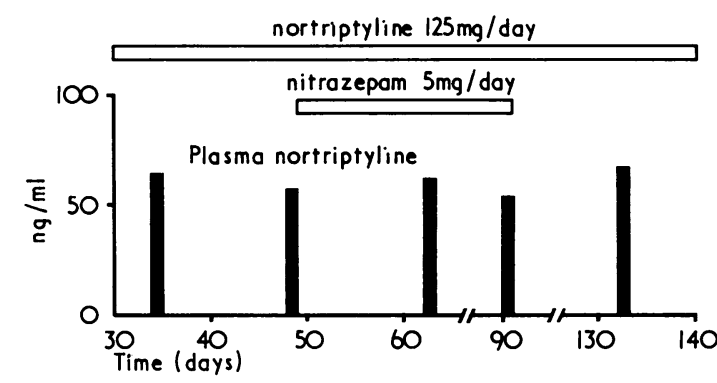

FIG. 1-Steady-state plasma nortriptyline levels in case 4 before, during, and after concomitant nitrazepam medication.

\section{Discussion}

The results strongly suggest that significant effects on nortriptyline and amitriptyline plasma levels do not occur with additional benzodiazepine medication, at least for nitrazepam, diazepam, oxazepam, and chlordiazepoxide. The absence of a detectable effect by chlordiazepoxide is particularly interesting. When using animal studies Conney (1967) found chlordiaz-

TABLE I-Mean Steady-state Plasma Nortriptyline Levels before and during Benzodiazepine Medication. Figures in Parentheses are Number of Levels Contributing to Mean

\begin{tabular}{|c|c|c|c|c|c|c|c|}
\hline \multirow{2}{*}{$\begin{array}{l}\text { Case } \\
\text { No. }\end{array}$} & \multirow[t]{2}{*}{ Sex } & \multirow{2}{*}{$\begin{array}{l}\text { Weight } \\
\text { (kg) }\end{array}$} & \multirow{2}{*}{$\begin{array}{c}\text { Dose of } \\
\text { (mortriptyline }\end{array}$} & \multirow[t]{2}{*}{ Benzodiazepine } & \multirow{2}{*}{$\begin{array}{c}\text { Dose of } \\
\text { Benzodiazepine } \\
\text { (mg/day) }\end{array}$} & \multicolumn{2}{|c|}{$\begin{array}{l}\text { Mean Plasma Nortriptyline before and during } \\
\text { Benzodiazepine Medication (ng/ml) }\end{array}$} \\
\hline & & & & & & Before & During \\
\hline $\begin{array}{l}1 \\
2 \\
3 \\
4 \\
5 \\
6 \\
7 \\
8 \\
9\end{array}$ & $\begin{array}{l}\text { M. } \\
\text { F. } \\
\text { F. } \\
\text { F. } \\
\text { M. } \\
\text { F. } \\
\text { M. } \\
\text { F. } \\
\text { M. }\end{array}$ & $\begin{array}{l}45 \\
62 \\
52 \\
63 \\
66 \\
76 \\
78 \\
61 \\
81\end{array}$ & $\begin{array}{r}100 \\
125 \\
100 \\
125 \\
100 \\
125 \\
100 \\
80 \\
100\end{array}$ & $\begin{array}{l}\text { Nitrazepam } \\
\text { Nitrazepam } \\
\text { Nitrazepam } \\
\text { Nitrazepam } \\
\text { Chlordiazepoxide } \\
\text { Chlordiazepoxide } \\
\text { Diazepam } \\
\text { Oxazepam } \\
\text { Chlordiazepoxide }\end{array}$ & $\begin{array}{r}10 \\
10 \\
5 \\
5 \\
20 \\
30 \\
8 \\
45 \\
40\end{array}$ & $\begin{array}{r}94(1) \\
177(2) \\
176(2) \\
62(2) \\
86(1) \\
63(3) \\
32(2) \\
167(2) \\
68(1)\end{array}$ & $\begin{array}{r}91(2) \\
160(1) \\
178(3) \\
58(2) \\
90(2) \\
63(3) \\
39(2) \\
169(4) \\
91(3)\end{array}$ \\
\hline
\end{tabular}

TABLE II-Mean Steady-state Plasma Amitriptyline and Nortriptyline Levels before and during Benzodiazepine Medication. Figures in Parentheses are Number of Levels Contributing to Mean

\begin{tabular}{|c|c|c|c|c|c|c|c|c|c|}
\hline \multirow{3}{*}{$\begin{array}{l}\text { Case } \\
\text { No. }\end{array}$} & \multirow{3}{*}{ Sex } & \multirow{3}{*}{$\underset{(\mathbf{k g})}{\text { Weight }}$} & \multirow{3}{*}{$\begin{array}{c}\text { Dose of } \\
\text { Amitriptyline } \\
\text { (mg/day) }\end{array}$} & \multirow{3}{*}{ Benzodiazepine } & \multirow{3}{*}{$\begin{array}{c}\text { Dose of } \\
\text { Benzodiazepine } \\
\text { (mg/day) }\end{array}$} & \multicolumn{4}{|c|}{$\begin{array}{l}\text { Mean Plasma Amitriptyline and Nortriptyline Levels before } \\
\text { and during Benzodiazepine Medication (ng/ml) }\end{array}$} \\
\hline & & & & & & \multicolumn{2}{|c|}{ Before } & \multicolumn{2}{|c|}{ During } \\
\hline & & & & & & Amitriptyline & Nortriptyline & Amitriptyline & Nortriptyline \\
\hline 10 & $\begin{array}{l}\mathbf{F} \\
\mathbf{M}\end{array}$ & 63 & $\begin{array}{l}80 \\
50\end{array}$ & $\begin{array}{l}\text { Diazepam } \\
\text { Diazepam }\end{array}$ & $\begin{array}{l}45 \\
25\end{array}$ & $\begin{array}{l}31(6) \\
78(2)\end{array}$ & $\begin{array}{l}40(6) \\
25(2)\end{array}$ & $\begin{array}{l}34(6) \\
90(3)\end{array}$ & $\begin{array}{l}33(6) \\
29(3)\end{array}$ \\
\hline
\end{tabular}




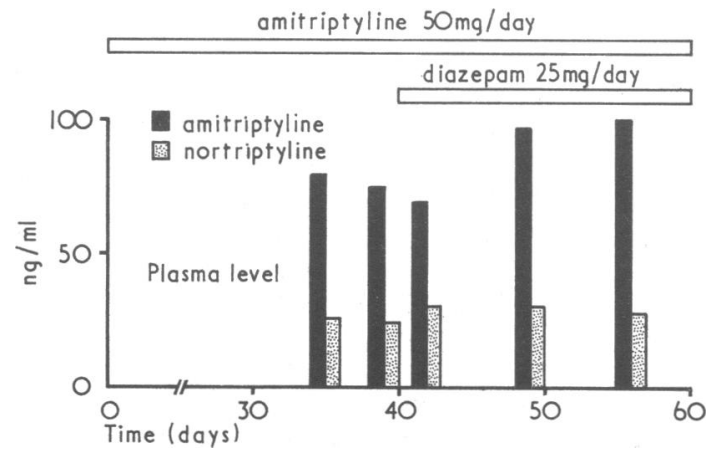

FIG. 2-Steady-state plasma amitriptyline and nortriptyline levels in case 11 before and during concomitant medication with diazepam.

epoxide to induce microsomal enzymes. Orme et al. (1972) again found evidence of enzyme induction by chlordiazepoxide in animals and also observed that it increased the excretion of urinary $6 \beta$-hydroxycortisol in two out of five of their patients. Increased excretion of this metabolite is thought to be an index of hepatic enzyme induction. In these two subjects, however, warfarin levels were not affected. The present study complements that of Orme et al. who found no interaction effects with nitrazepam, diazepam, or chlordiazepoxide and warfarin. It further stresses the need to measure the actual plasma levels of a particular drug before assumptions about this type of interaction can be made as other less direct indices may be misleading. The practical clinical implications of drug interactions are considerable. Starr and Petrie (1972) calculated the very sizeable risk that patients have of drug interactions when on maintenance anticoagulant therapy due to either selfmedication or additional drugs prescribed for them by other practitioners. It is possible that maintenance tricyclic antidepressant therapy may become common practice in view of the prophylactic value of this regimen reported by Mindham et al. (1972). Further, it is conceivable that failure in prophylaxis with just such treatment might result from the unwanted effects of intercurrent medication.

We gratefully acknowledge the help and encouragement of Professor F. A. Jenner, Dr. R. Goulding, and Dr. B. Widdop in this work. We are also indebted to Mr. E. Essex for his invaluable technical help.

Requests for reprints should be addressed to: Dr. G. Silverman, Whiteley Wood Clinic, Woofindin Road, Sheffield S10 3TL.

\section{References}

Alexanderson, B., Price-Evans, D. A., and Sjoqvist, F. (1969). British

Assberg, M., Cronholm, B., Sjoqvist, F., and Tuck, D. (1971). British Medical fournal, 3, 331 .

Braithwaite, R. A., Goulding, R., Theano, G., Bailey, J., and Coppen, A. (1972). Lancet, 2, 1297.

Braithwaite, R. A., and Widdop, B. (1971). Clinica Chimica Acta, 35, 461. Breckenridge, A., and Orme, M. (1971). Annals of the New York Academy of Sciences, 179, 421.

Burrows, G. D., and Davies, B. (1971). British Medical fournal, 4, 113.

Burrows, G. D., Davies, B., and Sloggins, B. A. (1972). Lancet, 2, 619.

Conney, A. H. (1967). Pharmacological Reviews, 19, 317.

Conney, A. H. (1969). New England fournal of Medicine, 280, 653.

Gram, L. F., and Overø, K. F. (1972). British Medical fournal, 1, 463.

Gruvstad, M. (1973). Lancet, 1, 95.

Hammer, W., Idestrom, C. M., and Sjoqvist, F. (1967). Excerpta Medica International Congress Series, $122,301$.

Kragh-Sørensen, P., Asberg, M., and Eggert-Hansen, C. (1973). Lancet, 1, 113.

Mindham, R. H. S., Howland, C., and Shepherd, M. (1972). Lancet, 2, 854.

Moody, J. P., Tait, A. C., and Todrick, A. (1967). British Fournal of Psychiatry, 113, 183 .

Orme, M., Breckenridge, A., and Brooks, R. V. (1972). British Medical fournal, 3, 611 .

Prescott, L. F. (1971). Scottish Medical fournal, 16, 121.

Starr, K. J., and Petrie, J. C. (1972). British Medical fournal, 4, 133.

\title{
E.E.G. and Personality Factors in Baby Batterers
}

\author{
SELWYN M. SMITH, LEO HONIGSBERGER, CAROL A. SMITH
}

British Medical fournal, 1973, 2, 20-22

\section{Summary}

Out of 35 parents who battered their children eight had an abnormal E.E.G. All of these were found to be psychopathic, of low intelligence, and to be persistent batterers. The presence of an abnormal E.E.G. strongly suggests that some baby batterers are more closely related to those who commit acts of violence and that taken as a whole they are not a homogenous group about whom it is safe to generalize. The possibility of a separate subgroup among baby batterers, therefore, needs close attention.

\footnotetext{
University Department of Psychiatry, Queen Elizabeth Hospital, Birmingham B15 2TH

SELWYN M. SMITH, M.B., M.R.C.PSYCH., Lecturer in Psychiatry CAROL A. SMITH, B.A., Research Associate

United Birmingham Hospitals

LEO M. HONIGSBERGER, M.B., M.R.C.PSYCH., Consultant Electroencephalographer
}

\section{Introduction}

Growing interest in the subject of "battered babies" has led to a belief that those who injure their children are not aggressive criminals but relatively normal persons who are exposed to unusual and excessive stress (Helfer and Kempe, 1968). The view has also been put forward that psychopathy is not a significant finding (Steele and Pollock, 1968). Despite this it has been shown that a high proportion of baby batterers have a history of blackouts or fits (Gibbens and Walker, 1956). Because of this and because we believe that insufficient emphasis has been placed on the possible organic background of this type of antisocial behaviour we decided to undertake an investigation of E.E.G. findings among baby batterers and any attendant abnormal personality correlates.

It is known that between 5 and $10 \%$ of the general population exhibit E.E.G. abnormalities (Hill and Watterson, 1942; Cobb, 1963). In selected groups such as university students and flying personnel E.E.G. abnormalities occur in fewer than $5 \%$ (Williams, 1941; Harding, 1973). In contrast, among those who are known to have committed acts of violence-for example, motiveless murder etc. - abnormalities may be found in $20 \%$ or more (Hill, 1943; Stafford-Clark and Taylor, 1949). 